\title{
Puff Pastry Practice Learning Using Search Engines
}

\author{
Dyah Nurani Setyaningsih ${ }^{1}$. Labbaika Rabbani ${ }^{2}$ \\ \{dyahnuranis@mail.unnes.ac.id $\left.{ }^{1}\right\}$
}

\author{
${ }^{1}$ Lecturer of Family Welfare Education Program, Universitas Negeri Semarang \\ ${ }^{2}$ Alumnus of Family Welfare Education Program, Universitas Negeri Semarang
}

\begin{abstract}
The search engine can contain all visual information, including the product of puff pastry. Along with the advancement of technology, it is easy for people to obtain information on the internet to learn something new. This research includes the $4^{\text {th }}$-semester students of the Culinary Department in UNNES who are taking the Pastry class. The sample covers total sampling. The variable of this sampling is the use of a search engine and the practical score of puff pastry creation. Data collected through a closed-ended questionnaire and documentation. The analysis of the data used the Pearson Correlation. The result of the research shows that there is a significant correlation between the use of the search engine and the practical score of puff pastry creation in the range of 0.598 in the significant rate of 0.00 with the linear connection on the ratio of 1.44434 .
\end{abstract}

Keywords: Search Engine, Learning Resources, Puff Pastry, Pearson Correlation.

\section{Introduction}

In the era of globalization, the advancement and development of technology are very fast. The development of technology will cover the fields of education. Academic search engines such as Google Scholar, IEEE Xplore, PubMed, and SciPlore.org, which greatly increased the ability of researchers to make their articles available to academics public. Like other types of ranking search results, articles displayed in the top positions are more likely to be read [1]. The internet is available with hundreds of thousands of web pages, it's better to use a search engine to reach data that is following what is needed or information [2]. The use of information technology makes the education process easier, through the internet, the source of information can be easily accessed. Learning source is a helpful source for students to learn in the learning process. Learning source comes from a textbook, printed media, electronic media, surrounding nature, et cetera [3]. Learning styles classify the various ways people learn and how they approach information; like acting and reflection; pay attention and listen; memorize and visualize; logical and intuitive reasoning $[4,5,6]$.

Learning style is considered important as a material consideration in the academic world education process which is also supported by a variety of available literature. Among other variables, differences in learning styles can be influenced by the language, the culture, the education department, and gender [6]. Learning source is a set of materials or situation which allows students to learn independently [7]. Learning source is a power that is used for the process of teaching and learning, directly or indirectly [8].

The most advanced learning resources come from the internet [9]. Internet as a medium that does not have restrictions on every Internet user information is very helpful for effectiveness and efficiency [10]. A search engine is a kind of software, which functions to collect data about a website. Data collected related indexed analyzed in the database. All of these operations are 
carried out by search engine software. They navigate web pages periodically and capture changes that occur to available websites [11].

In a modern class, there should be an internet connection. The integration of internet connection can help the teaching and learning process to be better in accessing the information, people browse and search on the internet [12]. People access search engines to look out information on the internet [13]. Search engine optimization is based on keywords that are suitable for the website and can be used for searching search engines. To optimize website browsing according to search engines, it must be following some technicalities conditions [14]. The higher and more frequently a site appears in search results, the more visitors who browse using the search engine [15].

The search engine has excellence in practicality amongst other learning sources. Through search engines, people can also get visual information. In this research, the author focuses on the use of a search engine for the learning of puff pastry. Puff pastry is a light and smooth pastry made of laminated dough that can be topped or filled, sweet or savory, allowing the emergence of a wide variety of products of pastry. Unlike other laminated baked goods such as croissants and Danish cakes, puff pastry is made from the unleavened dough without other developer ingredients $[16,17]$.

Puff Pastry is the queen of all pastry. Puff Pastry is a product of bakery from wheat flour, eggs, fats, and water through the oven healing process [18]. People get through this process by layering the cakes. To achieve the best layer, the chef should have strong accuracy and correct technique. Due to this reason, students in the culinary department consider that pastry is the most difficult unit to take.

From the initial observation, students should repeat the practice of making puff pastry in 2 to 3 times to produce the best product in the best criteria. The failure of the product happens since they cannot make a fluffy cake in different layers. In this material, many students are demanded to master it in detail through the existing learning sources. The learning sources come from handouts containing the materials of puff pastry from its ingredients through its procedures. However, conventional materials do not succeed in making the students understand, especially in explaining a certain technique. Therefore, a search engine is proposed to make students able to find information for making puff pastry, whether in texts, pictures, audios, or videos. It is expected that students can easily, practically, and completely comprehend the technique. The premise of this research is visual information in a search engine is better than the verbal information from the lecture. Hence, the research wants to find whether there is a correlation between the use of a search engine and the practical score of students in the puff pastry class.

\section{Methods}

This research was conducted to the Culinary Department of UNNES who takes Pastry class and practicing on making Puff Pastry. The population of this research is 41 students. The sample of this research is the whole population of it, which contains 30 female students and 11 male students. The variables of this research are 1) the use of a search engine, which includes the indicator of experience, quantity, quality as the independent variables, and 2) the practical score of puff pastry as the dependent variable. The data of this research came from documentation and questionnaire. The questionnaire was used to know the use of a search engine as the learning source specifically for the material of puff pastry. Meanwhile, the practical score of puff pastry came from the documentation. The writer analyzed the data from the correlating analysis of "Pearson Correlation" [19]. The correlation coefficient describes the strength and direct relationship between several variables. Pearson Correlation is a measure of 
linearly distributed relationships between two random variables [20]. Pearson correlation coefficient, also known as the product-moment correlation coefficient. The coefficient is measured on a scale with no unit and can take values from 0 to +1 [21].

\section{Results and Discussion}

Data were obtained through a questionnaire on the frequency of use of search engines as a reference in the media that are presented in the following diagram. The frequency of using search engines as a source of learning seems to be of high intensity, while none of the students have used search engines. No student never uses a search engine. Overall, the search engine completely helps the students in learning how to make puff pastry. The search engine helps students to obtain complete and quick information regarding puff pastry. Media cover people, materials, tools, activities, and behavior [22]. The search engine is an electronic librarian which helps the students to get a book based on a particular topic and author [23]. The use of a search engine is based on three indicators, which are experience, quantity, and quality as in the following table.

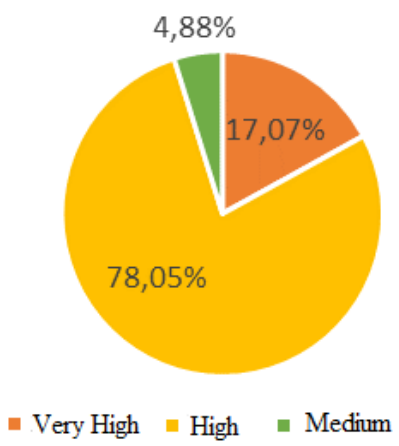

Fig. 1. The Frequency of Search Engine Utilization as Learning Sources.

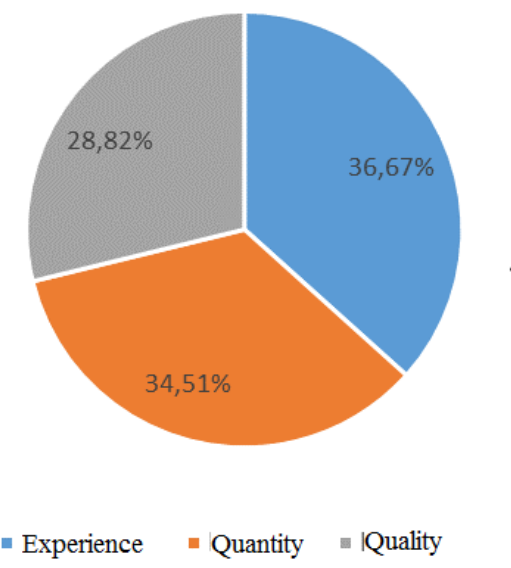

Fig. 2. The Indicator of Search Engine Utilization. 
The three indicators have the balances of experience, quantity, and quality of the use of a search engine. The average score of the students' experience is $36.67 \%$ or 3.3 out of 4 . Meanwhile, the quantity covers $34.51 \%$ or 3.1 , and the indicator of quality which is $28.82 \%$ or in the average score of 2.6. The result of the practical score can be seen in the following graph as follows.

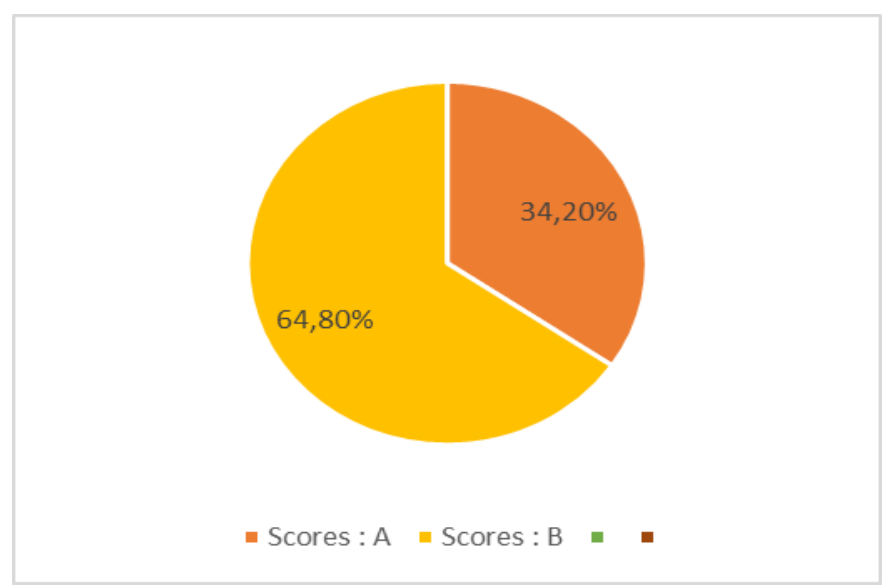

Fig. 3. Puff Pastry Practical Score.

The score of puff pastry creation shows that students are in the score of very good $65.85 \%$ of students got $\mathrm{AB}$, and $34.15 \%$ of them got $\mathrm{A}$. The practical score of puff pastry consists of preparation, process, and result. The above figure is the score which is obtained after the students use a search engine to find learning sources. The high score indicates that the learning process succeeds. The raw input, instruments, and environment are the influencing factors for the students in learning [24]. Learning outcome from vision sense is $75 \%$, hearing is $13 \%$, and others are 12\%. It is confirmed that the research from BAVA (British Audio Visual Aids, 1988) that the information from hearing sense is $13 \%$ while other senses are $87 \%$. The researches show that visual sense has a better influence than the others. In relevance to this research, the search engine helps the students to create a puff pastry from its visual information [25].

The correlation of the use of the search engine and the score of puff pastry through Pearson Correlation obtain the $\mathrm{r}$ hit $>\mathrm{r}$ table which is $0.598>0.308$ with the significance of 0.00 . The result indicates that there is a strong correlation between these variables. In detail, students tend to get a higher score if they use the search engine. The linear regression analysis shows that there is a same correlation that $\mathrm{Y}=\mathrm{A}+\mathrm{BX} ; \mathrm{r}=0.598$ where $\mathrm{B}($ slope $)=1.44434$; A (intercept $=83.7714) ; \mathrm{Y}=$ practical score and $\mathrm{X}=$ the use of search engine.

Through the application of Lectora Inspire, students obtain a better score than the use of textbooks ( $\mathrm{t}=9.226$ and $\mathrm{p}=0.004<\mathrm{a}=0.05$. 2) [26]. Meanwhile, the use of Computer-animated instruction (CAnI) has a positive effect on teaching students complex, abstract, and dynamic problems for the matriculation in Malaysia. The score was obtained from the open-ended questionnaire, pretest, and post-test [27].

There is a positive and significant effect on the use of Google to the learning result of economy class students from the XI IPS class. The students obtained a score of 3.144 for confidence with a 1.988 table score and the equation of 3.144>1.988 [28]. There is a positive and significant correlation from the use of the internet as the source of learning for the geography class of XII IPS, since rxy score is 0.556 which is higher than the $r$ Table score of 
$1 \%$, resulting in from the $\mathrm{r}$ score of 0.351 and $5 \%$ Table. The $\mathrm{r}$ score resulted 0.271 or rxy of 0.556 which is higher in $5 \%$ and $1 \%$ is $0.271<0.556>0.351$ [29].

The function of learning resources is to increase the success rate of students. There is a tendency of students who use search engines as a source of learning to have high grades and vice versa high scores on students are the intensity of their use of search engines is also high. Then, students can learn quickly and master the material better. Later, they can get a satisfactory score for the puff pastry class. This can be seen from the value of the correlation between the frequency of search engine users with the practicum value in making puff pastry.

\section{Conclusion}

The conclusion of this research contains a significant correlation between the use of a search engine and the result of practice in making puff pastry for the $4^{\text {th }}$-semester students in the culinary education program. The correlation score of this research is 0.598 in the significant rate of 0.00 and the linear correlation ratio of 1.44434. There is a positive and significant effect on the use of Google to the learning result. The search engine completely helps the students in learning how to make puff pastry.

\section{References}

[1] Beel, Joeran. Erik Wilde. Bella Gip. 2010. Academic Search Engine Optimization ( ASEO): Optimizing Scholarly Literature. Journal of Scholarly Publishing. https://www.researchgate.net/publication/200610396.

[2] Yalcin, Nursel. Utku Kose. 2010. What is search engine optimization: SEO?. WCLTA. Procedia Social and Behavioral Sciences 9 (2010) 487-493.

[3] Munir.2008. Kurikulum Berbasis Teknologi Informasi dan Komunikasi. Kerjasama UPI dengan Alfabeta. Bandung.

[4] Claxton,CS.,and P.H. Murrell. 1987. Learning styles: Implications for Improving Educational Practice. ASHE-ERIC Higher Education Report No. 4, Washington, DC: George Washington University.

[5] Schmeck, R.R., ed. 1988. Learning Strategies and Learning Styles. New York: Plenum Press.

[6] Gunduz, Nuket. Deniz Ozcan. 2010. Learning styles of students from different cultures and studying at Near East University. Procedia Social and Behavioral Sciences 9 (2010) 5-10. doi:10.1016/j.sbspro.2010.12.107.

[7] Siregar, Eveline. and Hartini Nara. 2010. Teori Belajar dan Pembelajaran. Bogor Ghalia Indonesia.

[8] Sudjana, Nana. and Ahmad Rivai. 2007. Teknologi Pengajaran. Bandung: Sinar Baru Algesindo.

[9] Rozi, Zaenal.2007.Mari Mengenal Internet.Kerjasama ANDI dan SmithDev Community Semarang.

[10] Puspita, R H., and D Rohedi. 2018. The Impact of Internet Use for Students. IOP Conf. Series: Materials Science and Engineering 306 (2018) 012106. doi:10.1088/1757899X/306/1/012106

[11] Iyiler, Z. 2009. Elektronik Ticaret Ve Pazarlama, T.C. Prime Ministry Undersecretariat of Foreign Trade Export.

[12] Bentley, Y., Selassie, H., Shegunshi, A. 2012. Design and Evaluation of Student-Focused e-Learning. Electronic Journal of E-Learning,10(1),1-12. https://doi.org/10.1007/s10648013-9243-1 
[13] Jasmadi.2004. Panduan Praktis Menggunakan Fasilitas Internet.Penerbit Andi. Semarang. [14] Sezgin, G.,(2009), Arama Motorlarnn Davranlarnn Çözümlenmesi Ve Web Sayfalarna Tasarm Aamasnda Yanstlmas, Master Thesis, Beykent Üniversity Institute for Science and Technology, Istanbul.

[15] Veglis, Andreas., and Dimitrios Giomelakis. 2019. Search Engine Optimization. Future Internet 2020. 12(6); doi:10.3390/fi12010006

[16] Cauvain, S.P.; Young, L.S. Baking Problems Solved, 1st ed.; Woodhead Publishing Limited: Cambridge, UK, 2001.

[17] Patil, Vedant. and Pranali Nikam. 2018. Development and Quality Evaluation of Puff Pastry (Fenugreek). International Journal of Chemical Studies 2019; 7(1): 2490-2493.

[18] Faridah, Anni., Kasmita S. Pada., Asmar Yulastri., Liswarti Yusuf. 2008. Patiseri Jilid 1. Direktorat Pembinaan Sekolah Menengah Kejuruan. Departemen Pendidikan Nasional. 190 pp. ISBN: 978-602-8320-82-5.

[19] Arikunto, Suharsimi. 2006. Prosedur Penelitian. PT Rineka Cipta. Yogyakarta.

[20] Schober, Patrick., Christa Boer, and Lothar A. Schwarte. 2018. Correlation Coefficients: Appropriate Use and Interpretation. International Anesthesia Research Society. Vol 126 (5): 1763-1768. DOI: 0.1213/ANE.0000000000002864.

[21] V.S. Gerlach \& D.P. Ely. 1980. Teaching \& Media: A Systematic Approach. Second Edition. MA: Allyn and Bacon. Pearson Education. Boston

[22] Sedgwick, Philip., 2012. Pearson's Correlation Coefficient. BMJ 2012;345:e4483 doi: 10.1136/bmj.e4483.

[23] Sanjaya, Wina. 2010. Perencanaan dan Desain Sistem Pembelajaran. Kencana. Jakarta.

[24]Purwanto, Ngalim .1990 Psikologi Pendidikan.PT Remaja Rosdakarya.Bandung.

[25] Tim Pengembang Ilmu Pendidikan.2007.Ilmu dan Aplikasi Pendidikan cetakan 2. Fakultas Ilmu Pendidikan UPI. Bandung.

[26]Zulfiati, H. M. 2014. Pengaruh Pembelajaran Ips Berbasis ICT (Information And Communications Technology) Dengan Aplikasi Lectora Inspire Dalam Meningkatkan Hasil Belajar Siswa. JIPSINDO, 1(1): 39-58.

[27] Talib, O., Matthews, R., \& Secombe, M. 2005. Constructivist Animations for Conceptual Change: An Effective Instructional Strategy in understanding complex, abstract, and Dynamic Science Concepts. Malaysian Online Journal of Instruction Technology Vol.2(3), December 2005: 78-87.

[28] Arumdani, Ita Marshelita., Bambang Wasito, Muhammad Sabandi. 2018. Pengaruh Pemanfaatan Situs Google sebagai Sumber Belajar dan Motivasi Belajar terhadap Prestasi Belajar pada Mata Pelajaran Ekonomi Kelas XI di SMA Negeri 3 Surakarta.BISE: Jurnal Pendidikan Bisnis dan Ekonomi. Volume 4(2) 2018. p-ISSN 2548-7175. https://jurnal.uns.ac.id/bise

[29] Khairani, Parida Anggriani, Eva Alviawati. 2014. Pengaruh pemanfaatan Internet sebagai Sumber Belajar terhadap Hasil Belajar Geografi Siswa Kelas XII IPS SMA Negeri 9 Banjarmasin.JPG (Jurnal Pendidikan Geografi) Vol 1(1) e-ISSN: 2356-5225. http://ppjp.unlam.ac.id/journal/index.php/jpg 